\title{
Arcybiskupa Życińskiego koncepcja związków między duchowością chrześcijańską a mediami (przyczynek do badań)
}

Ks. PROF. DR HAB. Wojciech Misztal

Prorektor Uniwersytetu Papieskiego Jana Pawła II w Krakowie

Arcybiskup Józef Mirosław Życiński (1948-2011) jest zaliczany do wybitnych polskich i katolickich duchownych oraz myślicieli końca XX i początku XXI stulecia. Pozostawił po sobie bogatą, pozwalającą czerpać z jego poglądów, spuściznę, m.in. w postaci publikacji i wypowiedzi dla mediów. Oparciem dla niniejszego opracowania będą słowa abp. Życińskiego udostępnione w Wikicytatach w haśle Józef Życiński ${ }^{1}$, czyli w zasobach cyfrowych o zasięgu światowym i stanowiących część jednego z ważniejszych współcześnie źródeł pozyskiwania informacji i kształtowania opinii².

1 http://pl.wikiquote.org/wiki/Józef_Życiński; dostęp: 3.02.2015 oraz 20.12.2015 ( $\mathrm{z}$ informacji o stronie wynika, że w tym czasie była ona modyfikowana; dane za https://pl.wikiquote.org/w/index.php?title=Józef_ Życiński\&action=info; dostęp 20.12.2015).

2 Zob. np. M. Różycka, Media publiczne a kształtowanie przemian społecznych, w: Naukowy Przegląd Dziennikarski 9(2014), s. 6-28; taż, 
Rzecz jasna wytypowane w ten sposób wypowiedzi abp. Życińskiego nie mogą być traktowane jako pozwalające w sposób wyczerpujący opracować wskazany w tytule temat. Jednak ze względu na znaczenie Internetu i dalej Wikipedii oraz Wikicytatów właśnie jako obecnie szeroko wykorzystywanego źródła danych należy liczyć się z tym, iż dla wielu odbiorców wypowiedzi te są czy będą podstawowym - jeśli wręcz nie jedynym - środkiem pozwalającym zapoznać się z myślą abp. Życińskiego i następnie znaleźć się w kręgu jej oddziaływania.

\section{Charakterystyka hasła Józef Życiński w Wikicytatach}

Jak już zostało zaznaczone, według dołączonej do hasła Józef Życiński strony internetowej „Informacje o «Józef Życiński» - Wikicytaty" hasło to zostało utworzone 23 lutego 2006 roku, czyli jeszcze za życia abp. Życińskiego. Zaś ostania jego edycja miała miejsce 17 grudnia 2013 roku, czyli nieco wcześniej niż na trzy lata od jego śmierci. Podano, że całkowita liczba edycji to 66. Długość strony w bajtach to $15259^{3}$. Na wydruku uzyskanym dzięki opcji drukowania, bez przeprowadzenia jakichkolwiek modyfikacji, hasło zajmuje nieco mniej niż 4,5 strony w formacie A4.

Społeczeństwo obywatelskie a media, w: Naukowy Przegląd Dziennikarski 7(2013), s. 6-29.

3 http://pl.wikiquote.org/w/index.php?title=Józef_Życiński\&actio$\mathrm{n}=$ info; dostęp: 20.12.2015. 
Biorąc pod uwagę dorobek, który arcybiskup Życiński pozostawił po sobie, nie jest to dużo. Na przykład katalog Biblioteki Narodowej dla zapytania „Życiński Józef” $z$ wyborem pola "autor” podaje 373 wyniki ${ }^{4}$. Zestawienie $z$ innymi podobnymi stronami wskazuje, że stajemy tu wobec wciąż palącego problemu obecności i dostępności dorobku wybitnych chrześcijan w Internecie. Jeśli zaś tam nie ma danych, to dla rzesz ludzi one w ogóle nie istnieją5. Już przed laty papież Paweł VI pisał: Kościół „czułby się winny przed swoim Panem, gdyby nie używał tych potężnych pomocy"6. Przytoczone słowa odnoszą się do sytuacji z 1975 roku, czyli możliwości dawane przez media były wtedy dużo mniejsze niż dzisiaj. Na problem ten zwrócił uwagę także papież Benedykt XVI. „(...) jeśli Dobra Nowina nie jest znana także w środowisku cyfrowym, to mogłaby być nieobecna w doświadczeniu wielu ludzi, dla których ta przestrzeń egzystowania jest ważna. Środowisko cyfrowe nie jest jakimś światem paralelnym lub czysto wirtualnym, lecz częścią codziennej rzeczywistości wielu osób"7. Przedstawione poniżej danej z drugiej strony

4 Dane za http://katalogi.bn.org.pl/iii/encore/search/C_Sa:(życiński józef)_Orightresult_U?lang=pol\&suite=cobalt, dostęp 28.12.2015.

5 Zob. orędzie papieskie o obecności Chrystusa w Internecie.

6 Paweł VI, Adhortacja apostolska o ewangelizacji w świecie współczesnym Evangelii nuntiandi (8.12.1975), nr 35; za: http://www.opoka.org. pl/biblioteka/W/WP/pawel_vi/adhortacje/evangelii_nuntiandi.html; dostęp 21.01.2014.

7 Benedykt XVI, Messaggio per la XLIV Giornata Mondiale delle Comunicazioni Sociali Il sacerdote e la pastorale nel mondo digitale: 
wskazują również, że działania polskie, które oczywiście powinny zostać pilnie długofalowo zintensyfikowane, nie wypadają najgorzej w stosunku do innych. Zapowiedziane informacje można przedstawić w formie tabeli ukazującej obecność wybitnych, bliskich sobie m.in. chronologicznie czy przez wypełniane zadania, myślicieli katolickich w Wikicytatach:

\begin{tabular}{|r|l|l|l|r|r|}
\hline Lp. & Postać & $\begin{array}{l}\text { Strona } \\
\text { utworzona }\end{array}$ & $\begin{array}{l}\text { Ostatnia } \\
\text { edycja }\end{array}$ & $\begin{array}{l}\text { Całkowita } \\
\text { liczba } \\
\text { edycji }\end{array}$ & $\begin{array}{l}\text { Długość } \\
\text { strony } \\
\text { w bajtach }\end{array}$ \\
\hline 1. & Jan Paweł II ${ }^{8}$ & 17.08 .2004 & 9.01 .2015 & 595 & $65482^{9}$ \\
\hline 2. & $\begin{array}{l}\text { Jean-Marie } \\
\text { Lustiger }\end{array}$ & 28.07 .2015 & 28.07 .2015 & 6 & $947^{11}$ \\
\hline 3. & $\begin{array}{l}\text { Carlo Maria } \\
\text { Martini }\end{array}$ & 29.09 .2007 & 5.11 .2015 & 76 & $16014^{13}$ \\
\hline
\end{tabular}

i nuovi media al servizio della Parola (24.01.2010), http://w2.vatican. $\mathrm{va} /$ content/benedict-xvi/it/messages/communications/documents/ hf_ben-xvi_mes_20100124_44th-world-communications-day.html, dostęp 1.03.2016.

8 Za: https://pl.wikiquote.org/w/index.php?title=Jan_Pawe\%C5\%82 II\&action=info; dostęp 20.12.2015.

9 Za: https://pl.wikiquote.org/w/index.php?title=Jan_Paweł_II\&action=info, dostęp 20.12.2015.

${ }_{10}$ Za: https://fr.wikiquote.org/wiki/Jean-Marie_Lustiger, dostęp 20.12.2015.

${ }_{11}$ Za: https://fr.wikiquote.org/w/index.php?title=Jean-Marie_Lustiger\&action=info, dostęp 20.12.2015.

12 Za: https://it.wikiquote.org/wiki/Carlo_Maria_Martini, dostęp 20.12.2015.

${ }_{13}$ Za: https://it.wikiquote.org/w/index.php?title=Carlo_Maria_Martini\&action=info, dostęp 20.12.2015. 


\begin{tabular}{|l|l|l|l|r|l|}
\hline Lp. & Postać & $\begin{array}{l}\text { Strona } \\
\text { utworzona }\end{array}$ & $\begin{array}{l}\text { Ostatnia } \\
\text { edycja }\end{array}$ & $\begin{array}{l}\text { Całkowita } \\
\text { liczba } \\
\text { edycji }\end{array}$ & $\begin{array}{l}\text { Długość } \\
\text { strony } \\
\text { w bajtach }\end{array}$ \\
\hline 4. & $\begin{array}{l}\text { Stefan } \\
\text { Wyszyński }{ }^{14}\end{array}$ & 12.11 .2004 & 30.11 .2015 & 116 & $40905^{15}$ \\
\hline 5. & Józef Życiński & 23.02 .2006 & 17.12 .2013 & 66 & 15259 \\
\hline
\end{tabular}

Dla porównania:

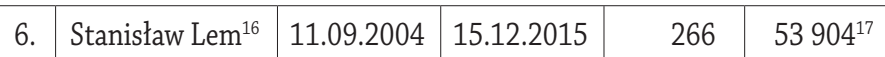

Powyżej przedstawione dane jednoznacznie wskazują, że gdy chodzi o zaznajamianie z myślą ks. abp. Życińskiego, jest jeszcze wiele do zrobienia.

Omawiane hasło dzieli się na cztery części: 1) zwięzła nota biograficzna: „Józef Mirosław Życiński (1948-2011) arcybiskup metropolita lubelski, profesor filozofii, teolog"; 2) kolorowe zdjęcie z podpisem; 3) 23 wypowiedzi abp. Życińskiego wraz z podaniem źródła i zasadniczo także daty opublikowania/emisji w przypadku periodyków i radia; słowa abp. Życińskiego to 827 wyrazów, 6066 znaków ze

14 Za: https://pl.wikiquote.org/wiki/Stefan_Wyszy\%C5\%84ski, dostęp 20.12.2015.

15 Za: https://pl.wikiquote.org/w/index.php?title=Stefan_Wyszyński\&action=info, dostęp 20.12.2015.

${ }_{16} \mathrm{Za}$ : https://pl.wikiquote.org/wiki/Stanisław_Lem, dostęp 28.12.2015.

${ }_{17} \mathrm{Za}$ : https://pl.wikiquote.org/w/index.php?title=Stanisław_Lem\&action=info, dostęp 28.12.2015. 
spacjami, nieco ponad 3,5 strony wydruku, według tych samych co powyżej zasad, w formacie A4; 4) 13 wypowiedzi o abp. Życińskim wraz z podaniem ich autora, źródła, daty i ewentualnie $z$ odsyłaczami (linki); wypowiedzi te to 536 wyrazów, 3920 znaków ze spacjami. Składające się na hasło wypowiedzi abp. Życińskiego różnią się objętością. Pochodzą z różnego czasu i z różnych źródeł. Zostały one zamieszczone w układzie alfabetycznym, biorąc pod uwagę pierwsze słowo cytowanego tekstu. W zbiorze tym nie wyróżniono żadnych kategorii tematycznych, nie dokonano też podziału ze względu na adresatów ${ }^{18}$.

W prawym górnym rogu prezentowanego hasła znajduje się kolorowe, wspomniane już, zdjęcie podpisane „Józef Życiński”. Przedstawia ono arcybiskupa na tle książek, czyli zbyt mało obecnie dostrzeganego nurtu społecznego przekazu, z dołączonymi do nich u góry kartkami jednakowego formatu i z taką samą grafiką. $Z$ tego, co można dostrzec na okładkach książek, wynika, iż są to publikacje o charakterze religijnym, chrześcijańskim, katolickim $^{19}$. Nasuwa się wniosek, że zdjęcie wykonane zostało

18 Natomiast takie rozwiązanie zostało zastosowane np. w przypadku znajdujących się w „Wikicytatach” haseł „Jan Paweł II” (http://pl.wikiquote.org/wiki/Jan_Pawe\%C5\%82_II; dostęp: 9.02.2015) i „Stefan Wyszyński" (http://pl.wikiquote.org/wiki/Stefan_Wyszy\%C5\%84ski; dostęp: 9.02.2015).

19 Zdjęcie także po przekierowaniu na plik o większej rozdzielczości nie pozwala na odczytanie informacji na przyczepionych do książek kartkach ani też tytułów publikacji. Podlinkowane zdjęcie w większej rozdzielczości: http://pl.wikiquote.org/wiki/ 
prawdopodobnie w czasie np. jednych z targów książek katolickich, czyli w „środowisku” medialnym. Zdjęcie przedstawia abp. Życińskiego z uśmiechniętą, pogodną, budzącą zaufanie twarzą, bez piuski, w czarnej marynarce i czarnej koszuli (lub czarnym clergymanie), z białą koloratką i krzyżem biskupim. W tytule strony http:// pl.wikiquote.org/wiki/Józef_Życiński brak informacji, że mamy do czynienia $z$ duchownym, jednak zdjęcie jednoznacznie na to wskazuje, uwydatniając przynależność do wyższego duchowieństwa, rangę biskupią. Przekaz medialny zdjęcia można ująć następująco: szczęście osobiste, bycie duchownym i związki z szeroko rozumianym przekazem medialnym nie wykluczają się, mogą występować razem u tej samej osoby. Taka interpretacja jest zbieżna z przytoczonymi następnie słowami abp. Życińskiego: „Nie mniej realna [...] jest [...] radość, którą mogę dzielić z bliskimi. Czymś zaś najważniejszym jest poczucie sensu tego, co robię. Cieszę się z niego zarówno jako filozof, jak i ksiądz"2o.

J\%C3\%B3zef_\%C5\%BByci\%C5\%84ski\#mediaviewer/File:Jozef_Zycinski_2008.jpg; dostęp: 7.02.2015.

20 J. Życiński, „Nie występuje w roli cierpiętnika”, „Duży Format”, 20.12.2004, w: „Józef Życiński”. Jak sugeruje kontekst, tytuł raczej brzmi „Nie występuję w roli cierpiętnika”. W niniejszym opracowaniu wskazania związane z pochodzeniem wypowiedzi abp. Życińskiego stosują się do danych, które zostały zamieszczone w haśle „Józef Życiński”. Taka zastosowana systematycznie metoda pozwala lepiej wyrobić sobie zadnie na temat analizowanego zbioru źródłowego m.in. przez zachowanie opisów, które trudno byłoby uznać za ściśle bibliograficzne. 
Uwzględniając podane daty publikacji wypowiedzi, otrzymujemy następujące zestawienia. 14 maja 2004 roku: trzy wypowiedzi (wszystkie z "Gazety Wyborczej”); 20 grudnia 2004 roku; 3 stycznia 2005 roku: trzy wypowiedzi (wszystkie z "Gazety Wyborczej”); 31 stycznia 2005 roku; 14 lutego 2005 roku; 21 lutego 2005 roku; 13 czerwca 2005 roku; 26 września 2005 roku; 15 stycznia 2007 roku: dwie wypowiedzi (obie z "Gazety Wyborczej”); 30 listopada 2007 roku; 27 marca 2008 roku; 15 kwietnia 2010 roku; 11 lutego 2011 roku; 12-13 lutego 2011 roku. Ostatnie dwie wypowiedzi ukazały się tuż po śmierci abp. Życińskiego (1o lutego 2011). W przypadku czterech wypowiedzi brak daty publikacji. Z tym że trzy z nich zostały zaopatrzone komentarzami pomocnymi dla ustalenia chronologii: 1) „Opis: po śmierci Jana Pawła II o podejściu Polaków do dorobku papieża”, 2) „Źródło: «Pięć dialogów»", 3) „Opis: komentarz do reakcji Anny Walentynowicz na opublikowanie teczki przez Lecha Wałęsę". Papież Jan Paweł II zmarł 2 kwietnia 2005 roku. Książka Pięć dialogów Gustawa Herlinga-Grudzińskiego i abp. Józefa Życińskiego ukazała się w 1999 roku. Lech Wałęsa opublikował swoją teczkę 10 czerwca 2007 roku. W jednym przypadku opis cytowanych słów sprowadza się do stwierdzenia: „podczas homilii”. Przytoczone wypowiedzi pochodzą z dziewięciu różnych, wymienionych z nazwy źródeł. Dziewiętnaście razy jest to "Gazeta Wyborcza”, dwa razy „Tygodnik Powszechny” (za każdym razem 
cytowany za „Gazetą Wyborczą"). Pozostałe wymienione w haśle źródła występują po jednym razie: „Duży Format”, „Dziennik Wschodni”, gazeta.pl, homilia, Pięć dialogów, Radio Plus, Radio Zet, „Trybuna”. Większość źródeł to periodyki drukowane, jeden raz prasa internetowa, dwa razy radio.

Słownictwo, które można (choćby ze względu na skojarzenia) zakalasyfikować jako religijne, dotyczące religii, duchowości w znaczeniu chrześcijańskim: 37 terminów bez uwzględnienia kontekstu. Mamy tu następującą listę (zaznaczono, jeśli dany termin występuje więcej niż jeden raz): Apostoł (w znaczeniu: jeden z Dwunastu Apostołów), autorytet, biskup, Bóg, celibat, chrześcijański, encyklika, Ewangelia, filozof, głoszenie, godność człowieka, Jan Paweł II (2 razy), Jezus, Jezus Chrystus, Judasz, kapłan, katolik, kościół (jako budynek), Królestwo Niebieskie, krzyż, krzyżyk, ksiądz, Matka Boża, metafizyka, miłość bliźniego, modlitewny, nieopętany, Ogrójec, opętany, Piotr, podstawowe prawa osoby ludzkiej, prawo do dobrego imienia, religia, sumienie, wierny (w znaczeniu: chrześcijanin, katolik), wyświęcać. Udostępniane wypowiedzi nie są więc nasycone taką terminologią. Brak w nich takich określeń jak np. asceza, ascetyka, duchowość, duchowość chrześcijańska, miłość do Boga, mistyka, modlitwa, Msza św., spowiedź, życie duchowe. Czy to oznacza, że abp Życiński nie podejmuje zagadnień związanych $\mathrm{z}$ duchowością? Jak przyjdzie zobaczyć, bynajmniej nie. 


\section{Rozumienie i współczesna rola duchowości chrześcijańskiej}

Termin „duchowość” jest wieloznaczny ${ }^{21}$. Samo w sobie nie jest to wadą. Szereg innych ważnych określeń też jest wieloznacznych. W tym kontekście warto przypomnieć następującą wypowiedź, która odnosi się do interpretacji nowotestamentalnych listów Pawłowych. Te jednak od prawie 2000 lat należą przecież do najbardziej oddziałujących na ludzkość przesłań ${ }^{22}$. Wpisują się w komunikację społeczną i świat mediów jako protagonista, należąc do istotnego nurtu przekazu pisemnego ${ }^{23}$, dają początek szeroko rozwiniętemu i wpływowemu piśmiennictwu chrześcijańskiemu. Stąd przytoczone poniżej słowa mogą dostarczyć pomocy, także gdy chcemy zrozumieć chrześcijańską, sprawdzoną w ciągu stuleci, koncepcję duchowości i skorzystać z niej. „Najlepiej jest rozumieć każde sformułowanie z nieprecyzyjnością, jaką posiadało w umyśle św. Pawła. Nieprecyzyjność jest znakiem bogactwa, nie zaś ubóstwa: Paweł brał pod uwagę wszystko to,

${ }_{21}$ Zob. np. wykaz znaczeń u: J.W. Gogola, Teologia komunii z Bogiem, wyd. II poprawione, Kraków 2003, s. 17-32; J. Mariański, Sekularyzacja, desekularyzacja, nowa duchowość. Studium socjologiczne, Kraków 2013, s. $148-170$.

${ }_{22}$ Zob. np. uwagi L. Bouyer, L. Dattrino, Storia della spiritualità, t. 3/a: La spiritualità dei padri (II-V secolo). Martirio - verginità - gnosi cristiana, Bologna 1986, s. 39.

${ }_{23}$ Zob. Franciszek, Orędzie na XLVIII Światowy Dzień Środków Społecznego Przekazu „Przekaz w służbie autentycznej kultury spotkania” (24.01.2014). 
co zawiera w sobie potencjalne pojęcia «Duch» $i$ «duchowy”"24. Oto jeszcze jedna, ważna dla podjętego zagadnienia wypowiedź. „Kardynał Daniélou (może nieco zanadto akcentując różnicę między greką a hebrajskim, ale za to w sposób pedagogicznie skuteczny) wyraził to następująco: «Gdy mówimy o 'duchu', gdy twierdzimy, że ‘Bóg jest duchem', to co właściwie chcemy powiedzieć? Czy mówimy po grecku, czy po hebrajsku? Jeśli mówimy po grecku, twierdzimy, że Bóg jest bytem niematerialnym itp. Jeśli mówimy po hebrajsku, twierdzimy, że Bóg jest huraganem, burzą, potęgą, której nie można się oprzeć. Stąd tyle wieloznaczności, gdy mówimy o duchowości. Czy duchowość polega na stawaniu się bytem niematerialnym, czy bytem ożywianym przez Ducha Świętego?»”25. Przytoczone słowa dostarczają ważnych elementów dla refleksji nad relacjami między duchowością chrześcijańską a mediami, gdzie przecież istotną rolę odgrywa oddziaływanie na zmysły i wielorakie zastosowanie rzeczywistości fizycznych, materialnych.

Duchowość w rozumieniu chrześcijańskim można zdefiniować jako podstawowe dla bytów ludzkich, w wystarczającym stopniu uświadomione, przeżywane związki

\footnotetext{
24 L. Cerfaux, Le Christ dans la théologie de saint Paul, wyd. 2-gie poprawione, Paris 1954, s. 223.

25 Y.M.-J. Congar, Wierzę w Ducha Świętego, tom I: Duch Święty w „ekonomii". Objawienie i doświadczenie Ducha, tłum. A. Paygert, Warszawa 1995, s. 38 .
} 
z Bogiem i z woli Boga także z bytami stworzonymi ${ }^{26}$. Jeżeli są to relacje z Bogiem, to mamy do czynienia z rzeczywistością nieskończenie przerastającą byt ludzki. Jako zasadniczy element na duchowość składają się wspomniane już związki człowieka jako stworzenia z otoczeniem, z potrzebującymi jego opieki, pomocy (zob. np. Mt 25, 31-46). W świetle Biblii trzeba tutaj wymienić nie tylko ludzi, ale także przewyższające ich byty duchowe ${ }^{27}$. Istotna jest kwestia, czy wykaz jest już kompletny: ku odpowiedzi przeczącej prowadzi m.in. tak fundamentalny tekst, jak List do Rzymian św. Pawła Apostoła (zob. Rz 8, 18-23) ${ }^{28}$. Podstawowym aspektem jest fakt, iż relacje z Bogiem i z otoczeniem mogą układać się różnie, w tym niewłaściwie. $\mathrm{Na}$ przykład może nawet dojść do konfliktu z Bogiem: wina jest tu zawsze po stronie istoty stworzonej. „O ile Bóg na złym stanie wskazanych związków nie traci - a przecież bardzo stara się On je ulepszać, bardzo zależy Mu na nich o tyle zły stan życia duchowego (duchowości) jednoznacznie i poważnie szkodzi istocie stworzonej. Widać, iż o duchowość trzeba dbać, promować ją, leczyć, starać się o jej rozwój, bo interesujące nas teraz związki mogą i powinny być coraz głębsze. Bóg chce, by te związki były coraz

${ }_{26}$ W. Misztal, Praca i duchowość, w: Studia Socialia Cracoviensia 8(2013), s. 51-52.

${ }_{27}$ Zob. A. Ganoczy, Nauka o stworzeniu, seria: Podręcznik teologii dogmatycznej, red. W. Beinert, t. 3, Kraków 1999, s. 96-105.

${ }_{28}$ Zob. A. Ganoczy, Nauka o stworzeniu, seria: Podręcznik teologii dogmatycznej, red. W. Beinert, t. 3, Kraków 1999, s. 55-56. 
doskonalsze, w zamiarze tym zawiera się ich niekończący się rozwój w życiu wiecznym. Czyli duchowość to nie tylko obrona przed grzechem, walka ze złem: ten aspekt jest bardzo ważny, należy do istoty duchowości, dominuje jednak jednoznacznie aspekt pozytywny"29.

Media, podobnie jak inne wymiary rzeczywistości, stanowią część związków ludzi z Bogiem i z ich otoczeniem. Kościół katolicki postrzega je jako wielki dar Boży wspomagający, a nawet znacząco wzmacniający docieranie z orędziem Ewangelii. Są one w istotnym związku z duchowością jako w znacznej mierze jej pochodna. Wpływają na nią. Zarazem korzystanie $\mathrm{z}$ nich i tworzenie ich to $\mathrm{w}$ znacznej mierze pochodna duchowości, jej jakości. Także w istotnej mierze same media, ich tworzenie, działanie i wykorzystanie są takie, jaka jest duchowość ich twórców i odbiorców. Dobrze obrazują to plusy i wyzwania związane np. z interaktywnością i forami oraz komentarzami internetowymi ${ }^{30}$.

29 W. Misztal, Mediajako sprzymierzeniec duchowości, w: Wartości w mediach - z dolin na szczyty, red. A. Baczyński, M. Drożdż, Tarnów 2012, s. 277.

3o Zob. np. Sobór Watykański II, Dekret o środkach społecznego przekazu myśli „Inter mirifica”; Paweł VI, Messaggio per la VII Giornata Mondiale delle Comunicazioni Sociali „Le comunicazioni sociali e l'affermazione e promozione dei valori spirituali" (1.05.1973); tenże, Adhortacja apostolska o ewangelizacji w świecie współczesnym „Evangelii nuntiandi” (8.12.1975), nr 45; Jan Paweł II, Orędzie na XXXIX Światowy Dzień Środków Społecznego Przekazu „W służbie wzajemnego zrozumienia między narodami” (24.01.2005), nr 1; Benedykt XVI, Messaggio per la XLVII Giornata Mondiale delle Comunicazioni Sociali „Reti Sociali: porte di verità e di fede; nuovi spazi di evangelizzazione” (24.01.2013); Franciszek, Orędzie na XLVIII Światowy Dzień Środków Społecznego Przekazu „Przekaz 


\section{Arcybiskup Życiński i komunikacja społeczna}

Będące punktem odniesienia hasło daje podstawy, by przedstawić następujący obraz relacji między abp. Życińskim a komunikacją społeczną. Przede wszystkim abp Życiński, czyli duchowny, nie ucieka przed komunikacją społeczną, w tym przed nowoczesnymi, potężnymi, opiniotwórczymi mediami. Ma z nimi do czynienia. Wypowiada się za ich pomocą. W przeważającej mierze są to media świeckie. Jednoznacznie abp Życiński działa jako aktywny uczestnik komunikacji społecznej. Omawiane hasło nie należy do obszernych. Jednakże przedstawione w nim jego wypowiedzi wskazują, iż podejmuje on szerokie spektrum tematów i tak właśnie przez media zwraca się do odbiorców. Oddziałuje na nich.

Zakres podejmowanej w haśle Józef Życiński tematyki można przedstawić, $z$ konieczności hasłowo, nie zaś wyczerpująco, w następujący sposób. $Z$ tym, iż należy pamiętać, że poszczególne wątki przeplatają się i nawet przenikają na kształt żywej tkanki, organizmu, co jest naturalne, ponieważ dotyczą tego samego życia ludzkiego. Jako duchowny - i to znany, zajmujący wysokie miejsce w hierarchii - abp Życiński wypowiada się na temat aktualnej polskiej polityki zagranicznej: i to tak ważnego i kontrowersyjnego zagadnienia,

w służbie autentycznej kultury spotkania" (24.01.2014). Zob. też P. Maciaszek, Nowa ewangelizacja przez nowe media, Kultura - Media - Teologia 11(2012), s. 13-15. 
jakim była misja wojskowa w Iraku ${ }^{31}$. Mamy do czynienia ze staraniami zaradzenia współczesnym wyzwaniom - czy aby trapiącym wyłącznie społeczeństwo polskie? - jak: błędne podejście do rozliczenia za różnego stopnia współpracę z komunizmem, zakłamywanie najnowszej historii, wybielanie winnych, trud obrony niewinności ${ }^{22}$, potrzeba pojednania społecznego, uznanie za możliwą przemianę życia na lepsze $^{33}$, zwalczanie pesymizmu ${ }^{34}$, korygowanie naiwnego gloryfikowania przeszłości35, niewłaściwego podejście do polityki i do wiary oraz życia społecznego, do związków między nimi ${ }^{36}$, wskazanie na bezpodstawność opinii, jakoby zniesienie celibatu i wyświęcanie kobiet na kapłanów zatrzymały

${ }^{31}$ J. Życiński, „Gazeta Wyborcza”, 3.01.2005, w: „Józef Życiński”.

32 J. Życiński, Gazeta Wyborcza”, 14.05.2004, w: „Józef Życiński”; tenże, Prawda historii a humanizm Ewangelii, „Tygodnik Powszechny”, 15.01.2007, w: „Józef Życiński”; tenże, komentarz do reakcji Anny Walentynowicz na opublikowanie teczki przez Lecha Wałęsę, brak daty, gazeta. pl, w: „Józef Życiński”; tenże, Sportowcy i arcybiskup promuja przeszczepy, „Dziennik Wschodni”, 27.03.2008, w: „Józef Życiński”.

33 Wypowiedzi abp. Życińskiego z "Gazety Wyborczej” 14.05.2004 i 14.02.2005, w: „Józef Życiński”.

34 J. Życiński, Gazeta Wyborcza”, 31.01.2005, w: „Józef Życiński”.

35 J. Życiński, „Gazeta Wyborcza”, 31.01.2005, w: „Józef Życiński”.

36 J. Życiński, z homilii, brak daty, „Gazeta Wyborcza”, 3.01.2005, w: „Józef Życiński”; tenże, Prawda historii a humanizm Ewangelii, „Tygodnik Powszechny”, 15.01.2007, w: „Józef Życiński”; tenże, „Trybuna”, 30.11.2007, w: „Józef Życiński”; tenże, „Trybuna”, 30.11.2007, w: „Józef Życiński”; tenże, opisane jako „po śmierci Jana Pawła II o podejściu Polaków do dorobku papieża”, brak daty, w: „Józef Życiński”; „Sportowcy i arcybiskup promują przeszczepy”, „Dziennik Wschodni”, 27.03.2008, w: „Józef Życiński”; tenże, „Gazeta Wyborcza” 12-13.02.2011, w: „Józef Życiński". 
dechrystianizację i przyczyniły się do rozkwitu katolicy$\mathrm{zmu}^{37}$, przypomnienie, że zadanie duchownych to głoszenie Ewangelii i ukazywanie ideałów Bożych, nie zaś zwalczanie takich czy innych partii politycznych ${ }^{38}$. Arcybiskup Życiński ocenia, skąd się brała siła systemów totalitarnych, w tym wskazuje na winę elit intelektualnych jako udzielających im poparcia ${ }^{39}$. Wskazuje też na wartość i konieczność właściwej wrażliwości sumienia, poszanowanie godności osoby ludzkiej, praw człowieka, w tym prawa do dobrego imienia ${ }^{40}$.

Czytając hasło, napotyka się na wątek dotyczący pozytywnego wpływu Jana Pawła II i tym samym wyznawanej i głoszonej przez niego religii ${ }^{11}$. Odbiorca znajduje też słowa wskazujące na życie ludzkie jako naznaczone codziennie krzyżem, decyzjami trudnymi, bo w ich konsekwencji bliźni może cierpiećt ${ }^{42}$. Na uwagę ze względu na błędną, a jednak ugruntowaną, tendencję do przedstawiania chrześcijaństwa jako religii smutku itp. ${ }^{43}$ zasługują

37 J. Życiński, „Gazeta Wyborcza”, 12-13.02.2011, w: „Józef Życiński”.

${ }^{8}$ J. Życiński, Radio Plus, 26.09.2005, w: „Józef Życiński”.

39 J. Życiński, Pięć dialogów, w: „Józef Życiński”.

40 J. Życiński, Prawda historii a humanizm Ewangelii, „Tygodnik Powszechny”, 15.01.2007, w: „Józef Życiński”.

${ }^{41}$ J. Życiński, Budujmy mosty zamiast okopów, „Gazeta Wyborcza”, 11.02.2011, w: „Józef Życiński”.

42 J. Życiński, Nie występuje w roli cierpiętnika, „Duży Format”, 20.12.2004, w: „Józef Życiński”.

${ }_{43}$ Zob. Franciszek, Esortazione apostolica sull' annuncio del Vangelo nel mondo attuale „Evangelii gaudium” (24.11.2013), nr 83; 135; tenże, Orędzie na XLVIII Światowy Dzień Środków Społecznego Przekazu "Przekaz w służbie autentycznej kultury spotkania” (24.01.2014). 
słowa o doświadczeniu radości i dzieleniu się nią z bliski$\mathrm{mi}^{44}$. Występuje też bardzo ważny z punktu widzenia duchowości i odnajdywania się, radzenia sobie w życiu wątek poczucia sensu tego, co się robi ${ }^{45}$, radości ze swej pracy, umiejętności, wiedzy, stanu życia ${ }^{46}$. Arcybiskup Życiński wskazuje też na przydatność, wręcz konieczność modlitwy, tym samym wiary (w znaczeniu chrześcijańskim), duchowości (w znaczeniu chrześcijańskim), by skutecznie stawić czoła trudnym czy wręcz tragicznym doświadczeniom ${ }^{47}$. Podobnie wypowiada się o kulturze solidarności w takich

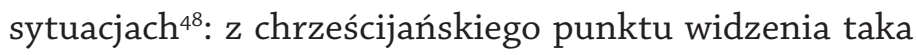
postawa przedstawia się jako realizacja miłości bliźniego. Z realizacją miłości bliźniego wiąże się także wypowiedź dotycząca przeszczepów narządów ${ }^{49}$. W uzmysławianie odbiorcom splotu, przenikania się relacji między religią i tym samym duchowością a innymi przestrzeniami ludzkiego życia wpisuje się ocena reakcji, w danym przypadku prawno-administracyjnej, na upowszechnianie się innej

44 J. Życiński, Nie występuje w roli cierpiętnika, „Duży Format”, 20.12.2004, w: „Józef Życiński”.

45 J. Życiński, Nie występuje w roli cierpiętnika, „Duży Format”, 20.12.2004, w: „Józef Życiński”.

${ }^{46}$ J. Życiński, Nie występuje w roli cierpiętnika, „Duży Format”, 20.12.2004, w: „Józef Życiński”.

47 J. Życiński, Za dużo moralistyki przy trumnach, „Gazeta Wyborcza”, 15.04.2010, w: „Józef Życiński”.

48 J. Życiński, Za dużo moralistyki przy trumnach, „Gazeta Wyborcza”, 15.04.2010, w: „Józef Życiński”.

49 J. Życiński, Sportowcy i arcybiskup promuja przeszczepy, „Dziennik Wschodni”, 27.03.2008, w: „Józef Życiński”. 
niż chrześcijaństwo religii, rozprzestrzenianie się w społeczeństwie oficjalnie areligijnym, w znacznej mierze zlaicyzowanym ${ }^{50}$.

\section{Relacje między duchowością chrześcijańską a mediami}

Duchowość jest bardzo ważnym wymiarem działalności abp. Życińskiego. Ksiądz Robert Nęcek zauważa: „Modlitwa była istotną częścią życia abp. Życińskiego. Przybrało to bardzo konkretną formę: wyraziło się w ofierze i pra-

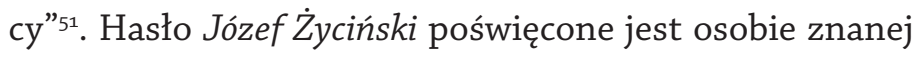
jako duchowny, wysokiej rangi hierarcha kościelny, myśliciel, uczony. To, co stanowi o tożsamości tej osoby, w haśle wydaje się przedstawiać omawiane już, znajdujące się na jego początku, zdjęcie oraz wypowiedź z 20 grudnia 2014 roku. Najpierw mamy tam słowa: „Czymś zaś najważniejszym jest poczucie sensu tego, co robię”. Zaraz potem abp Życiński dodaje: „Cieszę się z niego zarówno jako filozof, jak i ksiądz" (20 grudnia 2004). Słowa te sugerują, iż dla abp. Życińskiego do najważniejszych wartości w jego życiu należy właśnie bycie duchownym. W przytoczonym tekście warto zwrócić uwagę, że siebie samego określa on mianem „ksiądz”, oraz uwzględnić daty. Święcenia biskupie

\footnotetext{
5o J. Życiński, „Gazeta Wyborcza”, 14.05.2004, w: „Józef Życiński”.

${ }^{1}$ R. Nęcek, Ein Portrait des Lubliner Erzbischofs Józef Życiński (19482011), w: Theologisch-Praktische Quartalschrift (2014), nr 3, s. 298. 
przyjął on w 1990 roku i od tej pory kierował diecezją. Od 1997 roku był arcybiskupem metropolitą. Biorąc pod uwagę język i szeroko rozumianą kulturę polską, w tekście z 2004 roku raczej należałoby się spodziewać określenia „biskup”, , arcybiskup”, „metropolita”. Termin „ksiądz” stosowany jest zasadniczo w odniesieniu do prezbiterów. Natomiast intencja autora wydaje się jasna, gdy uwzględnimy, iż w milieu polskim termin „ksiądz” to także synonim względem „duchowny katolicki”. A zadaniem takiego człowieka, jak stwierdza abp Życiński, jest „ukazywanie ideałów Królestwa Niebieskiego"52.

Jeśli tak, to prezentowane w haśle działania, przemyślenia, słowa, czyny abp. Życińskiego są inspirowane i porządkowane przez relacje z Bogiem oraz przez troskę, by relacje z Bogiem układały się jak najlepiej u innych. Oznacza to jednak, że tym samym troska ta dotyczy także jakości relacji międzyludzkich. Uzasadnione w takim razie jest założenie, że inne wymienione w omawianym haśle wypowiedzi abp. Życińskiego to wyraz i narzędzie takiego właśnie przekonania. Jeżeli to rozumowanie jest słuszne, to dostarcza klucza także dla koncepcji związków między duchowością chrześcijańską a mediami, koncepcji wynikającej z jego przemyśleń i stanowiącej zasadę jego relacji z mediami.

Arcybiskup Życiński nie stroni od mediów, ich licznych i zróżnicowanych twórców i odbiorców, nie uważa ich za

52 J. Życiński, Radio Plus, 26.09.2005, w: „Józef Życiński”. 
z natury złych czy za narzędzie zła. Kontaktuje się z nimi. Wchodzi w dialog. Korzysta z właściwego im potencjału. Podobnie przedstawiają się relacje w drugim kierunku. Media niejako stają się dla niego, jak to można określić za Pawłem VI, jedną z ambon, niezbędnym i potężnym narzędziem wyrażania duchowości i pielęgnowania jej, dzięki nim może zwracać się do jak największej liczby odbiorców, jednocześnie uwzględniając to, co indywidualne ${ }^{53}$.

Współczesna cywilizacja żyje i rozwija się pod znakiem mediów, a nawet z oznakami pewnej ich dominacji. Zarazem wywodząca się nie tylko z przeszłości, ale i z wieczności (zob. np. Ef 1, 3-11) duchowość pozostaje ważna, aktualna w świecie współczesnym, także w relacji do nowych technologii. Duchowości, jak pokazuje abp Życiński, nie można i nie trzeba się wstydzić, należy ją „ukazywać”, dzielić się nią, kształtować życie za jej pomocą. Relacje między duchowością chrześcijańską a mediami są możliwe i potrzebne. Mogą one być owocne dla obu stron. Duchowość trzeba w związku z tym prezentować, czynić obecną w mediach i przez media. Będące podstawą do niniejszych uwag wypowiedzi nie dyskwalifikują pod tym względem środków społecznego przekazu świeckich. Dają one duże możliwości.

Media, ludzie mediów są zainteresowani duchowością, kształtowaniem jej. Z wypowiedzi abp. Życińskiego

53 Zob. Paweł VI, Adhortacja apostolska o ewangelizacji w świecie współczesnym „Evangelii nuntiandi” (8.12.1975), nr 45. 
zamieszczonych $w$ analizowanym haśle wynika, że jest on świadom takiego zainteresowania, wręcz zapotrzebowania. W konsekwencji nasuwają się pytania co do przyszłej pozycji chrześcijaństwa. Media udostępniają swój potencjał przekazu duchowości. Są na nią otwarte. Potrzebują jej. Pod tym względem nie przedstawiają się one gorzej niż inne wymiary życia, a ludzie mediów nie są gorsi niż inni ludzie. Duchowość jest związana z życiem ludzkim jako takim, nie można jej wyizolowywać, wygradzać dla jakiejś grupy ludzi, dla jakiegoś jednego obszaru ludzkiego życia. Mamy tu do czynienia z wzajemnym przenikaniem się, oddziaływaniem, niesieniem pomocy, co nie oznacza jednak, że musi dojść do utraty tożsamości czy jakiegoś zawłaszczenia ${ }^{54}$.

\section{Podsumowanie}

Prezentowane wypowiedzi ukazują abp. Życińskiego jako człowieka świadomego dużego pozytywnego potencjału duchowości chrześcijańskiej i mediów. Duchowość ta oraz świat środków społecznego przekazu nie są odizolowanymi od siebie środowiskami, konkurentami czy wrogami. One się przenikają, potrzebują wzajemnie, by zrealizować swe misje. Razem mają do wypełnienia ważne

54 Zob. G. Łęcicki, Teologia mediów audiowizualnych jako wyzwanie XXI wieku, w: Kultura - Media - Teologia 10(2012), s. 16-17. 
zadanie, jakim jest kształtowanie poszczególnych osób, kształtowanie społeczności.

Media - Kultura - Dialog. W piątą rocznicę śmierci arcybiskupa Józefa Życińskiego, red. ks. R. Nęcek, ks. W. Misztal, Kraków 2017, s. 53-74.

DOI: http://dx.doi.org/10.15633/9788374385848.09 